$\begin{array}{llllllllllll}\bar{A} & \mathrm{R} & \mathrm{T} & \mathrm{Y} & \mathrm{K} & \mathrm{U} & \mathrm{E} & \mathrm{Y}\end{array}$

\title{
Ferdynand I Koburg w oczach prześmiewców. Uwagi na temat bułgarskiej satyry politycznej przełomu XIX i XX wieku
}

Zarys treści: Autor analizuje ewolucję wizerunku księcia (a później cara) Bułgarii Ferdynanda I Koburga (1887-1918) w bułgarskiej twórczości satyrycznej z przełomu XIX i XX wieku: zbiorze opowiadań Baj Ganio Aleko Konstantinowa, poemacie satyrycznym Księga narodu bułgarskiego Stojana Michajłowskiego, wybranych opowiadaniach oraz felietonach Georgiego Kirkowa oraz karykaturach publikowanych w czasopiśmie humorystycznym „Byłgaran”. Niniejsze satyry stanowią zawoalowany komentarz nie tylko do aktualnych wydarzeń politycznych, w których Koburg brał czynny udział, ale i do zmieniającej się roli monarchy na bułgarskiej scenie politycznej oraz specyfiki bułgarskiego rojalizmu.

Outline of content: The author analyses the evolution of the image of Ferdinand I, Knyaz, and later Tsar of Bulgaria (1887-1918) in Bulgarian satire at the turn of the $19^{\text {th }}$ and $20^{\text {th }}$ century: a collection of short stories about Bay Ganyo by Aleko Konstantinov, the satirical poem Book on the Bulgarian People by Stoyan Mihaylovski, selected short stories and newspaper columns by Georgi Kirkov and caricatures published in the satirical periodical „Bulgaran”. These examples of satire are a veiled comment on not just current political events that Ferdinand I took an active part in, but also on the evolving role of the monarch on the Bulgarian political scene and the specifics of Bulgarian monarchism.

Slowa kluczowe: Ferdynand I Koburg, satyra polityczna, Bułgaria, Bałkany, XIX-XX wiek, rojalizm

Keywords: Ferdinand I Coburg, political satire, Bulgaria, Balkans, 19th-20th Century, royalism

\section{Uwagi wstępne}

Po powstaniu państwa bułgarskiego w 1878 r. wśród tamtejszej inteligencji panowało powszechne przekonanie o niespełnieniu wielkich odrodzeniowych marzeń o wolności narodu, zaprzepaszczeniu ich przez „nuworyszy” i „parwe- 
niuszy" oraz moralnym upadku władzy i społeczeństwa. W bułgarskiej debacie publicznej szczególne miejsce zajmowała satyra polityczna ${ }^{1}$, rozwijająca się w literaturze, publicystyce oraz sztuce. Służyła ona nie tylko obnażaniu czy ośmieszaniu patologii w funkcjonowaniu władzy, ale i mobilizowaniu odbiorców do angażowania się w sprawy publiczne. Charakter satyry, popularnej w Bułgarii w okresie panowania Ferdynanda I Koburga, był specyficzny - za jej dominantę należy uznać przede wszystkim dążenie do demaskacji patologii polityczno-społecznych, a nie komizm.

Ferdynand urodził się 26 lutego $1861 \mathrm{r}$. w Wiedniu, był członkiem rodu Sachsen-Coburg-Gotha, dokładnie jego katolickiej gałęzi Koháry, synem oficera w armii austriackiej księcia Augusta i córki ostatniego władcy Francji z dynastii Burbonów, Klementyny Orleańskiej². Przyszły książę Bułgarii był blisko spokrewniony z koronowanymi głowami ówczesnej Europy: królem Portugalii Ferdynandem II, królową brytyjską Wiktorią czy królem Belgii Leopoldem II. Młodość spędził w Wiedniu, gdzie, idąc w ślady ojca, wstąpił do szkoły oficerskiej, którą skończył w 1886 r. ze stopniem porucznika armii austro-węgierskiej. Rok później otrzymał propozycję objęcia tronu bułgarskiego (wcześniej odmówił tego książę Danii Waldemar). Kraj był pogrążony wówczas w poważnym kryzysie - w $1885 \mathrm{r}$. doszło do zjednoczenia Księstwa Bułgarii z Rumelią Wschodnią (zdominowaną przez Bułgarów prowincją Imperium Osmańskiego), co doprowadziło do konfliktu zbrojnego z Serbią, serii przewrotów, abdykacji pierwszego nowożytnego władcy Bułgarii Aleksandra Battenberga (1879-1886) i izolacji międzynarodowej młodego państwa. Zapatrzony w karierę polityczną członków dynastii oraz licząc na realizację ambicji politycznych, Ferdynand nie baczył na trudną sytuację na Bałkanach i przyjął propozycję Bułgarów. Przez pierwsze lata panowania monarcha był uznawany za uzurpatora przez większość władców europejskich i faktycznie znajdował się w cieniu Stefana Stambołowa, lidera frakcji antyrosyjskiej, który w 1886 r. zaprowadził w Bułgarii rządy dyktatorskie ${ }^{3}$. Należy jednak podkreślić fakt, że książę Ferdynand był głównym beneficjentem polityki zagra-

1 Satyra jest pojęciem niejasnym, którego znaczenie zostało rozszerzone do tego stopnia i odnosi się do tylu kategorii, że nie sposób posłużyć się tym terminem bez uprzedniego doprecyzowania jego definicji. Na użytek niniejszej pracy zdecydowałem się na przyjęcie definicji zaproponowanej przez Tomasza Stępniaka, który ujmuje satyrę jako „fenomen ponadliteracki, interartystyczny i intersemiotyczny, funkcjonujący między literaturą ( «piękną» $\mathrm{i}$ «stosowaną»), plastyką oraz formami audiowizualnymi, między tzw. "czystą» sztuką i działaniem w życiu publicznym”, przy czym jego „warunkiem (...) sine qua non jest krytyczny stosunek do świata, wyrażony poprzez jedną z postaci komizmu (od patetycznego sarkazmu po subtelną ironię i pure nonsens)". T. Stępniak, O satyrze, Katowice 1996, s. 78.

2 Ferdynand I Koburg doczekał się kilku biografii, z których warto wymienić: J. Knodt, Ferdinand der Bulgare, Bielefeld 1947; S. Constant, Foxy Ferdinand, 1861-1948, Tsar of Bulgaria, Londyn 1986; И. Йовков, Кобургът, Sofia 1990.

3 Zob. A. Страшимиров, Диктаторгт. Животът на Стебан Стамболов, Sofia 2014, s. 141-207; D. M. Perry, Stefan Stambolov and the Emergence of Modern Bulgaria 1870-1895, Londyn 1993, s. 127-232. 
nicznej Stambołowa, który, skupiając się na wyjściu z izolacji międzynarodowej Bułgarii, wzmacniał jednocześnie legitymizm i pozycję monarchy ${ }^{4}$. W 1894 r., wykorzystując aferę wokół rzekomego romansu Stambołowa z żoną ministra wojny, Ferdynand odsunął dyktatora od władzy i doprowadził do ukonstytuowana rządu złożonego ze swoich współpracowników z Konstantinem Stoiłowem na czele. Od upadku reżimu Stambołowa następowało wyraźne umocnienie pozycji monarchy w państwie. Powrócono do praktyki sprzed zjednoczenia formowania gabinetów odgórnie - premierem nie zostawał przywódca zwycięskiej partii czy koalicji w wyborach do Zgromadzenia Narodowego, lecz był on wyłaniany na zasadzie umowy księcia z przywódcą danej grupy. Partie polityczne znalazły się w cieniu Ferdynanda Koburga, który ze względu na częste zmiany kursu polityki zagranicznej zyskał przydomek „lisa Bałkanów” lub „Machiavellego z Sofii” ${ }^{\circ}$. Rozpoczął się okres reżimu monarszego w Bułgarii, trwający faktycznie do końca pierwszej wojny światowej ${ }^{6}$. Najwyraźniejszą egzemplifikacją dominującej pozycji monarchy w państwie były decyzje V Wielkiego Zgromadzenia Narodowego w 1911 r., na mocy których car (tytuł ten Ferdynand przyjął w 1908 r. wraz z ogłoszeniem przez Bułgarię niepodległości) uzyskał prawo do zawierania oraz negocjowania układów z innymi państwami bez konsultacji z parlamentem, czyli faktycznie mógł prowadzić politykę zagraniczną na własną rękę̨. Panowanie Ferdynanda Koburga skończyło się jednak tragicznie dla Bułgarii - cara uznaje się za głównego winowajcę klęski Bułgarii w czasie wojen bałkańskich oraz pierwszej wojny światowej, co doprowadziło do dotkliwych strat terytorialnych, porażki w odbudowanie „Wielkiej Bułgarii” i wreszcie abdykacji władcy w 1918 roku.

Konstytucja Bułgarii przyznawała szerokie kompetencje monarsze, co było dorobkiem starań konserwatystów oraz Rosjan w czasie obrad Zgromadzenia Ustawodawczego w 1879 roku. Na mocy ustawy zasadniczej książę był naczelnym dowódcą sił zbrojnych zarówno w czasie pokoju, jak i wojny, reprezentował Bułgarię $\mathrm{w}$ stosunkach z innymi państwami, miał szerokie uprawnienia wykonawcze (wszystkie urzędy i instytucje działały w jego imieniu i pod jego nadzorem) oraz ustawodawcze (obok inicjatywy ustawodawczej, zatwierdzał uchwalane przez parlament ustawy), do tego mógł rozwiązać Zgromadzenie Narodowe przed końcem kadencji ${ }^{8}$. Jego kompetencje zwiększyły się wyraźnie w okresie „reżimu pełnomocnictw”,

4 R. Crampton, Bulgaria, Oxford 2007, s. 139-140.

5 T. Wasilewski, Historia Bułgarii, Wrocław 1988, s. 221; А. Димов, Злодеяния на Кобургите в България, Sofia 2013, s. 15.

6 R. Crampton, op. cit., s. 150-188; История на Третата българска държава, red. Д. Саздов, М. Лалков, Т. Митев, Р. Мишев, В. Мигев, Sofia 1992, s. 161-162.

7 Е. Стателова, Иван Евстратиев Гешов или трвнливият пвт на съзиданието, Sofia 1994, s. 196-199; М. Палангурски, Нова история на България, t. I: Княжество (1879-1911), Sofia 2013, s. $284-287$.

8 Konstytucja tyrnowska (fragment), [w:] Historia Bułgarii 1870-1915. Materiały źródłowe z komentarzami, t. 3: Polityka wewnętrzna, red. J. Rubacha, A. Malinowski, Warszawa 2009, s. 67-68; B. Rusin, Konstytucja tyrnowska z 1879 r. - historia, ustrój, język, [w:] Historyczna i ponowoczesna tożsamość Słowian, red. T. Ciesielski, J. Zatorska, A. Skoczylas, Łódź 2012, s. 81. 
kiedy wprowadzono wiele rozwiązań autokratycznych ${ }^{9}$. Z drugiej strony młoda monarchia bułgarska podlegała procesom sekularyzacji władzy, które przebiegały wówczas w całej Europie: książę panował nie z „Bożej łaski”, a z „,woli narodu” (który formalnie go wybrał), a desakralizacja tronu oraz brak tradycji rojalistycznej sprawiały, że nawet daleko posunięta krytyka monarchy nie stanowiła tabu ${ }^{10}$. Artyści tworząc satyry wymierzone w księcia Ferdynanda byli jednak w pierwszej kolejności ograniczani przez przepisy chroniące wizerunek władcy. Teoretycznie konstytucja tyrnowska odrzucała wszelką formę cenzury oraz gwarantowała wolność słowa ${ }^{11}$, w praktyce jednak prawo prasowe wprowadzone na początku 1881 r., wzorowane na osmańskim, zabraniało krytykowania osób publicznych, w pierwszej kolejności monarchy ${ }^{12}$. Zostało ono rozszerzone w styczniu 1904 r. o prawo o przestępstwach na łamach prasy przeciwko głowie państwa i członkom jego rodziny, co było konsekwencją wydarzeń w Serbii z 1903 r., gdzie doszło do zamachu stanu i zamordowania króla Aleksandra Karadziordzievicia ${ }^{13}$. Osobę księcia uznano za „świętą i nietykalną", za nawoływanie do zmiany lub zniesienia instytucji monarchii groziła kara więzienia od 5 do 10 lat i grzywna w wysokości 5-10 tys. lewów ${ }^{14}$.

Mimo tych ograniczeń prasowych przełom XIX i XX wieku był w Bułgarii okresem rozkwitu satyry politycznej. Wydawano wiele czasopism humorystycznych, jak „Byłgaran” („Българан”15), „Śmiech i łzy” („Смях и сълзи”, 1898-1899), „Śmiech” („Смях”, 1900, 1911-1915), „Gorycz i Śmiech” („Жлъч и смях”, 1901), „Żądło” („Жило”, 1902), „Co Jest?” („К“во да е?”, 1902-1903, 1911-1922), „Baraban” („Барабан”, 1908-1921), „Chantecler” („Шантклер”, 1911) czy „Świerszcz” („Шурец”, 1913) ${ }^{16}$. Satyra polityczna rozwijała się także w literaturze oraz publicystyce - za najważniejszych satyryków tego okresu uznaje się Aleko Konstantinowa, Georgiego Kirkowa, Stojana Michajłowskiego,

9 „Reżim pełnomocnictw” (1881-1883) był okresem autokratycznych rządów księcia Aleksandra Battenberga w Księstwie Bułgarii. Został on wprowadzony przy współpracy z Petersburgiem, rosyjscy generałowie $\mathrm{z}$ czasem jednak przejęli dominującą rolę $\mathrm{w}$ państwie. Battenberg, by odsunąć środowisko generała Leonida Sobolewa od władzy, zdecydował się na ugodę z frakcją liberałów skupionych wokół Dragana Cankowa oraz na przywrócenie systemu konstytucyjnego w państwie. Zob. Г. Тодоров, Временно отменяне и възстановяне на конституцията в Княжество България (1881-1883), Sofia 1991; W języku polskim: K. Popek, „Kłótnia $w$ rodzinie”. Upadek protektoratu rosyjskiego $w$ Księstwie Bułgarii w latach 1879-1887, „Studenckie Zeszyty Naukowe UJ”, 2012, nr 4, s. 105-120.

10 J. Osterhammel, Historia XIX wieku. Przeobrażenie świata, tłum. I. Drozd-Broering, J. Kałążny, A. Peszke, K. Śliwińska, Poznań 2013, s. 773-791.

11 A. Nowosad, Władza i media w Bułgarii, Kraków 2008, s. 117.

12 Ibidem, s. 130-132, 144-145.

13 W. Felczak, T. Wasilewski, Historia Jugosławii, Wrocław 1985, s. 373-374.

14 A. Nowosad, op. cit., s. 169.

15 Tytuł czasopisma stanowi nieprzetłumaczalną deformację słowa българин - 'Bułgar'.

16 D. Parusheva, „They are All Rotters!” Political Culture and Political Caricature in South-Eastern Europe, Late 19th and Early 20th Century, „Études Balkaniques”, 2008, t. 44, nr 4, s. 50-52; К. Павлова, Образът на бай Ганьо в карикатурите от българския хумористично-сатиричен периодичен печат (1895-1944), [w:] Феноменбт Бай Ганьо в българската фолклорна и литературна култура от първата половина на ХХ век, red. М. Кирова, К. Йорданова, Н. Папучиев, Sofia 2013, Liternet.bg, www.liternet.bg/ebook/fenomenyt-baj-ganjo/content.htm [dostęp 3.04.2015]. 
Dimitra Podwyrzaczowa oraz Georgiego Stamatowa ${ }^{17}$. Ich celem stał się w dużej mierze władca Bułgarii Ferdynand I Koburg, czemu trudno się dziwić, gdyż był on jedną z centralnych figur życia politycznego Bułgarii przełomu XIX i XX wieku. To spowodowało, że ogrywał on ważną rolę w utworach satyrycznych z tego okresu. Najlepszym tego przykładem są: cykl opowiadań Baj Ganio (Бай Ганьо, 1894-1895) Aleko Konstantinowa, poemat Księga narodu bułgarskiego (Книга за българския народ, 1897) Stojana Michajłowskiego, opowiadania oraz felietony Georgiego Kirkowa z lat 1897-1900 czy karykatury z czasopisma „Byłgaran” (1904-1909).

Trzeba pamiętać, że wspomniane ograniczenia miały istotny wpływ na kreowania wizerunku monarchy przez wyżej wymienionych satyryków, którzy, by nie narazić się na procesy sądowe, często, choć nie zawsze, starali się prezentować księcia Ferdynanda w zawoalowany sposób, ograniczający się do aluzji, sugestii, dwuznaczności. $\mathrm{Z}$ tego powodu postać monarchy w wielu przypadkach była zastępowana wizerunkami tureckich paszów, wilków, pawi, treserów psów, rzeźników, lalkarzy, chińskich mandarynów, potworów czy rycerzy.

Na wstępie należy podkreślić, że niniejszy artykuł nie odnosi się do całego okresu panowania Ferdynanda Koburga, a tylko do lat 1894-1909. Jest to motywowane nie tylko okresem powstawania materiału źródłowego, ale także rozwojem bułgarskiej cenzury w tym czasie. Do 1894 r., czyli do upadku reżimu Stambołowa w Bułgarii panowała wyjątkowo ostra cenzura, do której powrócono także w okresie konfliktów zbrojnych lat 1912-1918. Wiele czasopism satyrycznych w okresie wojen bałkańskich i pierwszej wojny światowej zostało zamkniętych (np. „Żądło”), a te, które nadal były wydawane, musiały przyjąć retorykę prorządową i wstrzymać się od krytykowania bułgarskich władz (np. „Śmiech”, „Co Jest?”, „Baraban”). Tymczasem wśród pisarzy panowały przeważnie nastroje patriotyczne, związane z ideą skupienia wszystkich sił narodu na zwycięstwie i odbudowie „Wielkiej Bułgarii”, co powodowało, że nie było miejsca na drwiny z ówczesnych decydentów politycznych ${ }^{18}$.

\section{Baj Ganio Aleko Konstantinowa}

Aleko Konstantinowa uznaje się za jednego z klasyków literatury bułgarskiej, w cieniu pozostaje natomiast jego działalność polityczna - był członkiem Partii Demokratycznej, autorem pierwszego programu politycznego tej formacji, redaktorem jej organów prasowych, na łamach których publikował większość swoich tekstów ${ }^{19}$. Jego dorobek literacko-publicystyczny można traktować jako komen-

17 Nie można zapominać, że elementy satyryczne pojawiały się także u innych czołowych pisarzy bułgarskich tego okresu (np. Iwan Wazow, Penczo Sławejkow, Elin Pelin, Michałaki Georgiew, Kirił Christow), choć nie stanowiły one dominanty ich twórczości. Zob. С. Игов, История на българската литература 1878-1944, Sofia 1990, passim.

18 A. Nowosad, op. cit., s. 44-52; T. Dąbek-Wirgowa, Historia literatury bułgarskiej, Wrocław 1980, s. 195; Български периодччен печат 1844-1944, t. 1, red. П. Иванчев, Sofia 1966, s. 78, 291-292, 390; Български периодичен печат 1844-1944, t. 2, red. П. Иванчев, Sofia 1966, s. 320.

19 Програми, програмни документи и устави на бържоазните партии в Бблгария 1879-1918, red. В. Николова, Д. Саздов, Sofia 1992, s. 164; И. Мешеков, Бай Ганьо - психологически и обще- 
tarz dotyczący rzeczywistości polityczno-społecznej Bułgarii końca XIX wieku - w ten sposób często interpretuje się zbiór opowiadań satyrycznych Baj Ganio, niewątpliwie jego najważniejsze dzieło ${ }^{20}$. Głównym bohaterem cyklu jest stereotypowy Bułgar (wąsaty, paradujący w tradycyjnym stroju jegomość, bezpośredni, grubiański, głośny, skąpy, chciwy typ cwaniaka), trudniący się handlem olejkiem różanym, który podróżuje po Europie i doświadcza humorystycznych perypetii związanych z różnicami kulturowymi. Późniejsza część zbioru opowiadań dotyczy kariery politycznej baj Gania po jego powrocie do Bułgarii, kiedy to staje się on typowym przedstawicielem pozbawionej skrupułów elity młodego państwa. Dzieło Konstantinowa pokazywało więc w krzywym zwierciadle rzeczywistość społeczno-politycznej Bułgarii końca XIX wieku, która łączy w sobie wszystkie negatywne cechy Europy Zachodniej (ślepą pogoń za sukcesem, skrajny indywidualizm, materializm) oraz osmańskich Bałkanów (bierność społeczna, przywiązanie do autokratycznych rządów, brak postaw obywatelskich) ${ }^{21}$. W utworze nie zabrakło także zawoalowanych aluzji dotyczących charakteru monarchizmu w Bułgarii końca XIX wieku oraz ewolucji pozycji Ferdynanda Koburga przed załamaniem się reżimu Stambołowa i po jego upadku.

W opowiadaniach Aleko Konstantinowa idea monarchizmu jest przedstawiony jako pusty frazes (albo, jak nazywa ją jeden z bohaterów, ,jezuickie frazesy”22), co objawia się pod hasłem „Niech żyje Jego Carska Mość, wypowiadanym i zapisywanym przy każdej okazji przez baj Gania i jego popleczników (w manifestach politycznych, artykułach prasowych, listach czy na spotkaniu Towarzystwa Abstynentów ${ }^{23}$ ). Sentencja ta nie ma żadnego związku z wyższymi wartościami, aurą otaczającą tron,

ствен тип, [w:] Страници за Алеко Константинов: Творчеството на писателя в българската литературна критика, red. П. Анчев, Warna 1991, s. 137. Więcej o bułgarskiej Partii Demokratycznej zob. Д. Саздов, Демократическата партия в България 1887-1908, Sofia 2001.

20 Ten sposób interpretowania Baj Gania zdominował bułgarskie literaturoznawstwo w okresie komunizmu. Odczytywanie tego utworu satyrycznego w kluczu ideologii marksistowskiej doprowadziło do daleko idących uproszczeń interpretacyjnych: Dimityr Błagoew widział w postaci baj Gania „rycerza kumulacji kapitału”, a Georgi Bakałow - „ojca bułgarskiego faszyzmu”. Todor Pawłow zaklasyfikował Aleko Konstantinowa jako przedstawiciela socrealizmu (podobnie jak czołowego poetę odrodzenia narodowego Christo Botewa), co należy uznać za bezpodstawną, a wręcz absurdalną tezę. Zob. Г. Бакалов, Алеко Константинов и бай Ганьо, [w:] Страници за Алеко Константинов..., s. 110-131; Б. Ангелов, Алеко Константинов, [w:] Страници за Алеко Константинов..., s. 55-57; Ц. Д. Димитрова, Анализ върху критиката за „Бай Ганио” до 1918 2., [w:] Феноменът Бай Ганьо...

21 Р. Даскалов, Между Изтока и Запада. Български културни дилеми, София 1998, s. 172-176; R. Daskalov, Modern Bulgarian Society and Culture through the Mirror of Bai Ganio, „Slavic Review”, 2001, vol. 60, no. 3, s. 537-538 et passim.

22 A. Konstatinow, Baj Ganiu, tłum. F. Korwin-Szymanowski, Warszawa 1986, s. 93; Termin ten nawiązuje do pejoratywnego obrazu jezuitów utożsamianego w kulturze bułgarskiej (a także prawosławnej) z podstępem i zdradą. G. Minczew, „Watykańscy szpiedzy” i zdrajcy narodu w XIX wieku w Bułgarii, [w:] Obraz zdrajcy i szpiega w kulturach słowiańskich, red. T. Dąbek-Wirgowa, Warszawa 1999, s. 116-117.

23 A. Konstatinow, op. cit., s. 102, 129, 142, 146. 
sacrum, a nawet z podstawowym szacunkiem, jakim przyjęło się obdarzać głowę państwa. Patos odnoszący się do osoby monarchy przyjmuje formę groteskową, czego przykładem może być porównanie księcia Ferdynanda do „ojca narodu”, absurdalne w kontekście niemieckiego pochodzenia władcy, który nawet nie znał języka bułgarskiego ${ }^{24}$. W podobnym tonie autor ironizuje na temat prawa o ochronie wizerunku osoby i cenzury panującej w państwie: „Naród chce wiedzieć - śmiało mogę to stwierdzić - kiedy zostanie ucięta świętokradcza ręka opozycji, która o zgrozo! - śmie dotykać świętej i nieskalanej Osoby naszego wspólnego Ojca, tego, który jest Rękojmią szczęścia i dobrobytu nas wszystkich"25.

Wszystkie komplementy formułowane pod adresem księcia Ferdynanda Koburga przez obóz rządzący (niezależnie, czy związany ze Stefanem Stambołowem czy Konstantinem Stoiłowem, a reprezentowany przez baj Gania i jego popleczników) w utworach Konstantinowa mają wymiar wyłącznie praktyczny, konformistyczny, skalkulowany na uzyskanie korzyści politycznych. Hasła rojalistyczne stanowią więc gest ślepego posłuszeństwa i wyraz serwilizmu wobec monarchy, który jako pierwsza osoba w państwie jest $\mathrm{w}$ stanie zaoferować konkretne profity w postaci wpływów, stanowisk czy po prostu pieniędzy. Poddańcze wyrazy lojalizmu są warunkiem zachowania przychylności księcia, w czym prześcigają się poszczególni działacze polityczni, partie, rząd i opozycja:

Widzisz, jak wołam: „Niech żyje!”, a ty chcesz ludziom wmówić, że niby jestem przeciwko. Zazdrościsz mi, ty diable. A pamiętaj: jeśli zaczniemy się przekrzykiwać, nie wiadomo, kto kogo przekrzyczy. Jak przyjdzie do bicia czołem, też nie dam za wygraną. Ty ucałujesz rękę, ja - obie, ty ucałujesz kolana, ja - stopy, ty pocałujesz z przodu, ja - z tyłu. Ze mną chcesz ty się mierzyć, szczeniaku? ${ }^{26}$

W ten sposób Ferdynand jest przedstawiony jako władca otaczający się ludźmi, którzy potrafią się wyłącznie podlizywać. Dwór w opowiadaniach Aleko Konstantinowa stanowi zdegenerowane środowisko miernot - cechy charakteru, wykształcenie czy zdolności przywódcze nie stanowią kryterium doboru otoczenia władcy, liczą się jedynie ślepe posłuszeństwo oraz serwilizm.

Z drugiej strony powyższe fragmenty z Baj Gania można interpretować jako wyraz przedmiotowego wykorzystywania przez bułgarskich polityków haseł, związanych z monarchizmem, oraz samej osoby Ferdynanda Koburga, co odzwierciedla pozycję, w jakiej znalazł się książę w okresie reżimu Stambołowa ${ }^{27}$. W sposób nieco bardziej zmetaforyzowany Konstantinow oddał ten problem także w opowiadaniu Baj Ganiu w pałacu na święconem (Бай Ганьо в двореияa), w którym książęcy dwór został przedstawiony jako miejsce, gdzie można się wyłącznie „nażreć”28.

24 Ibidem, s. 95; S. Constant, op. cit., s. 93; А. Димов, op. cit., s. 13-14, 42.

25 A. Konstatinow, op. cit., s. 153.

26 Ibidem, s. 142.

27 R. Crampton, op. cit., s. 138.

28 A. Konstatinow, op. cit., s. 133-135. 
Czas powstania opowiadań Aleko Konstantinowa (1892-1895) był okresem zmiany statusu politycznego monarchy, co także znajduje wyraz w tych utworach. Autor uchwycił początek kształtowania się reżimu monarszego w Bułgarii oraz stopniowego przesuwania się ośrodka decyzyjnego władzy do pałacu (wszakże baj Ganio i jego poplecznicy skandują poddańcze hasła adresowane przede wszystkim do księcia, a nie premiera, konkretnej partii czy rządu). W manifeście pisanym przez tytułowego bohatera opowiadania Baj Ganiu z powrotem w Bułgarii (Бай Ганьо се върна от Европа) stwierdza się, że w praktyce to nie wybory, ale monarcha odgórnie ustanawia rząd, co było jedną z ważniejszych podstaw funkcjonowania „osobistego reżimu" Ferdynanda Koburga. Fragment ten stanowi bezpośrednią aluzję do pierwszego tego typu rozwiązania od początków panowania Koburga, czyli powołania drugiego rządu Konstantina Stoiłowa w maju $1894 \mathrm{roku}^{29}$.

Jednocześnie pozycja władcy na scenie politycznej umacnia się proporcjonalnie do pomnażania przez niego majątku dynastii, co zostało w bezpośredni sposób przedstawione przez Konstantinowa w opowiadaniu $Z$ korespondencji baj Gania Bałkańskiego (Из кореспонденцията на бай Ганьо Балкански):

Znaleźli się nawet tacy rozbójnicy pióra, którzy nie omieszkali powstrzymać i splugawić najszlachetniejszego odruchu serc wieśniaczych, wyrażającego się w darowaniu Majestatycznemu Ulubieńcowi gromadzkich lasów i łąk. Wielkość tronu jest zarazem wielkością narodu, (...) zamiast skakać z radości, że nasza do niedawna dzika ziemia pokrywa się wspaniałymi pałacami i willami, my, a raczej niektórzy spośród nas - niestety, są tacy Bułgarzy - nawet są $\mathrm{z}$ tego niezadowoleni ${ }^{30}$.

Nie były to bezpodstawne zarzuty - w latach dziewięćdziesiątych XIX wieku książę Ferdynand był najbogatszym człowiekiem w państwie: miał rezydencje w Ewksinogradzie, Kriczimie, Wrani, Saragiołdzie, Carskiej Bistricy i na Carewcu w Tyrnowie oraz majątki o łącznej powierzchni dziesiątek tys. hektarów ${ }^{31}$.

\section{Księga narodu bułgarskiego Stojana Michajłowskiego}

Stojan Michajłowski zasłynął nie tylko jako poeta, ale również jako działacz polityczny, który do końca życia nie związał się z żadną z partii: był dwukrotnie wybierany na deputowanego w Zgromadzeniu Narodowym (1894-1896, 1903-1908) oraz zaangażował się w ruch na rzecz przyłączenia Macedonii do Bułgarii (w latach 1901-1905 był prezesem Naczelnego Komitetu Macedońsko-Adrianopolskiego, tzw. wyrchowistów). Przez dwie dekady prowadził on krucjatę przeciwko upadkowi obyczajowemu, materializmowi oraz demoralizacji władz i społeczeństwa, zapisując się w historii jako jeden z najbardziej wyrazistych satyryków bułgarskich

29 Ibidem, s. 95; История на Третата..., s. 161.

30 A. Konstatinow, op. cit., 154.

31 T. Wasilewski, op. cit., s. 227-228; Zob. Д. Гочев, Е. Георгиев, И. Шалафов, Истината за изарските имоти в България, Sofia 2011. 
przełomu XIX i XX wieku. Obok Poematu zła (Поема на злото, 1889) za najważniejsze dzieło Michajłowskiego uznaje się poemat satyryczny Księga narodu butgarskiego, utwór oparty na monologu wielkiego wezyra Abdulrachamana paszy, który w formie pouczeń instruuje swojego następcę Galiba efendiego o tajnikach rządzenia państwem. Utwór stanowi traktat o bezprawiu, przemocy i przewrotności władzy, demaskujący dominujące w polityce oraz społeczeństwie $z_{ł o}{ }^{32}$. Wydźwięk poematu oraz cel, jaki przyświecał jego powstaniu, w trafny sposób podsumował Wojciech Gałązka:

Ze względu na potrzebę obrony (...) statusu apriorycznej demokracji, Księga narodu bułgarskiego jest jednocześnie księgą o narodzie, który nie umie jeszcze wprowadzić jej w życie i bronić (dlatego umieszczony jest po drugiej stronie Wschodu), i księgą dla narodu, dającą mu pamięć i wiedzę o autorytarnych zasadach sprawowania władzy, by mógł się przekonać, czy żyje w demokracji, czy pozostaje w rękach despoty ${ }^{33}$.

W pierwszej kolejności utwór ma wymiar uniwersalny - autor dążył do napisania „encyklopedii zła” ${ }^{4}$, do przeprowadzenia analizy mechanizmów władzy stosowanej przez tyranów na całym świecie od zarania dziejów, stworzenia idealnego antywzoru sprawowania rządów. Badacz twórczości Michajłowskiego Dimityr Michajłow zwraca jednak uwagę, że utwór nie przez przypadek powstał w rzeczywistości politycznej Bułgarii drugiej połowy lat dziewięćdziesiątych XIX wieku, czyli w momencie umacniającego się reżimu monarszego ${ }^{35}$. Część badaczy twierdzi nawet, że właściwie Księga narodu bułgarskiego jest w pierwszej kolejności wymierzona przeciwko osobie Ferdynanda Koburga, a Abdulrachman pasza stanowi jego zorientalizowane uosobienie ${ }^{36}$.

Główny bohater poematu Michajłowskiego jest pozbawionym skrupułów oraz moralności tyranem, dla którego utrzymanie władzy jest nadrzędną $\mathrm{i}$ jedyną wartością w życiu. Monarcha został w utworze przedstawiony jako wyznawca założeń makiawelizmu, spośród których bułgarski poeta szczególnie zaakcentował rozdzielenie polityki od wszelkich zasad moralnych: „A w tej nauce przede wszystkim pierwsza / podstawowa, i jeszcze raz pierwsza zasada brzmi: / «By władać - demoralizuj!»"37. Ideałem władcy dla Ferdynanda-Abdulrahmana jest odczłowieczona istota, wyzbyta jakichkolwiek uczuć, dla której stanowią one jedynie utrudnienie w rządzeniu państwem $^{38}$. Wyrachowanie oraz konformizm prowadzą monarchę do ciągłej zmiany

32 Д. Михайлов, Стоян Михайловски: поредица, творчески портрети, Sofia 1994, s. 100-103.

33 W. Gałązka, Oswajanie skorpionów. Szkice o literaturze bułgarskiej, Kraków 1992, s. 51.

34 A. Nowosad, op. cit., s. 159.

35 Д. Михайлов, op. cit., s. 100-101.

36 Ibidem, s. 103; П. Зарев, Панорама на българската литература, t. 2, Sofia 1977, s. 96-97.

37 „А в таз наука всепотребна първо / начало, първо правило това е: / «За да господаруваш - развращавай!»". С. Михайловски, Книга за българския народ, [w:] idem, Избрани творби, red. Б. Банов, Sofia 1976, s. 296.

38 Ibidem, s. 301. 
masek, przyjmowania postaw zależnych wyłącznie od sytuacji, co sprawia, że takie kategorie jak prawda czy fałsz, dobro czy zło nie istnieją dla niego ${ }^{39}$. Ten sposób prezentacji głównego bohatera poematu nawiązuje do złej sławy księcia Ferdynanda, którą zawdzięczał oportunizmowi, podstępności oraz umiłowaniu intryg, traktowaniu polityki jako gry ${ }^{40}$. W opowiadaniach Konstantinowa idee monarchistyczne sprowadzone są do pustych haseł, u Michajłowskiego nie ma już na nie miejsca. Dla demonicznego Ferdynanda-Abdulrahmana każda forma obudowywania władzy ideologią jest niepraktyczna, niepotrzebna, wręcz niebezpieczna. Moralność zostaje przez tureckiego paszę przedstawiona jako kamień wrzucony do delikatnych trybików maszyny do rządzenia ${ }^{41}$, a wprost określana mianem szaleństwa ${ }^{42}$. Władza monarchy zasadza się na nihilizmie - nie jest sprawowana ani „z Bożej łaski” (szczególnie w obliczu okrzyknięcia się przez władcę nawet nie mianem Boga, lecz całej religii: ,ja jestem Islamem!”43), ani „Z woli narodu” (traktowanego jako „bezmyślne stado małp" "44). Książę Ferdynand nie jest przedstawiony jako człowiek, który rządzi dla samego rządzenia - władza jest dla niego narzędziem do stawiania siebie ponad prawem: „Bierz sam, co tylko chcesz: wszystko, / co ci potrzeba, jest twoje! / Władza to zajazd, gdzie chytrusy / zajmują najrozkoszniejsze pokoje"45.

W rzeczywistości Ferdynand daleko odbiegał od wyimaginowanego geniusza zła, przedstawionego w Księdze narodu bułgarskiego pod postacią Abdulrahmana paszy. Rządy zaprowadzone przez Koburga nigdy nie dorównały „idealnej tyranii” Michajłowskiego, a autokratyzm w Bułgarii nie przybrał w pełni zaprezentowanej w omawianym poemacie formy jednowładztwa. Mimo odgórnego powoływania rządu oraz koncentracji władzy, monarcha wciąż musiał liczyć się z parlamentem oraz wynikami wyborów, a ze względu na słabość aparatu urzędniczego oraz instytucji państwowych (związanych chociażby z powszechną korupcją), kontrola wszystkich obszarów funkcjonowania państwa była zawodna i nieskuteczna ${ }^{46}$. Można powiedzieć, że autor przecenił wszechwładzę Ferdynanda Koburga. W gruncie rzeczy sposób prezentacji monarchy w najsłynniejszym poemacie Michajłowskiego stanowi echo recepcji machiawelizmu oraz osiemnastowiecznej myśli francuskiego oświecenia. Od klasycystów autor zaczerpnął sposób wykorzystania „orientalnej maski”, która w Księdze narodu bułgarskiego odgrywa niewątpliwie istotną funkcję.

39 Ibidem, s. 320.

40 А. Димов, op. cit., s. 12-13; A. Malinowski, Polityka i pieniądze. Wielkie mocarstwa wobec Bułgarii i jej udziału w I wojnie światowej na przełomie 1914 i 1915 r., [w:] I Wojna Światowa na Bałkanach. Działania militarne i polityczne w latach 1914-1918, red. A. Krzak, Szczecin 2014, s. 13.

41 С. Михайловски, op. cit., s. 311-313.

42 Ibidem, s. 305.

43 Ibidem, s. 331.

44 Ibidem, s. 313.

45 „Вземи си сам каквото искаш: всичко, / което би ти трябвало, е твое! / Властта е хан, където хитреците / завземат най-разкошните салони". Ibidem, s. 299.

46 T. Czekalski, Bułgaria, Warszawa 2010, s. 50-51; М. Палангурски, op. cit., s. 334-346; Przykładem na to, jak trudno było utrzymać rządy autokratyczne w Bułgarii był „reżim pełnomocnictw”, który funkcjonował zaledwie przez dwa lata. 
Po pierwsze, przedstawienie księcia Ferdynanda jako paszy tureckiego ma podkreślać obcość monarchy wobec narodu, jego niemieckie korzenie, dystans wobec poddanych oraz niezdolność zaadaptowania się do bułgarskiej rzeczywistości. Po drugie, Michajłowski za pomocą tego zabiegu formułuje zarzut ciągłości „jarzma osmańskiego" w Bułgarii oraz porażki poniesionej w budowaniu nowoczesnego państwa, które aspiruje do stania się częścią Europy. Ferdynand jest przedstawiony jako ideowy spadkobierca sułtanów tureckich, który ciemięży naród i manipuluje nim, podobnie jak czynili to padyszachowie przez pięćset lat niewoli ${ }^{47}$. Ta charakterystyka nabiera wymiaru groteskowego przez łączenie elementów wewnętrznie sprzecznych: Koburg jest orientalnym mędrcem (w literaturze oświecenia pełnił on funkcję toposu skarbnicy filozofii życia i prawd moralnych), przyjmującym postawę nihilistycznego, pozbawionego skrupułów tyrana stawiającego siebie ponad prawem $^{48}$. Nie można zapomnieć także o ostatniej z funkcji „orientalnej maski” poematu - jest ona sposobem na uniknięcie cenzury oraz oskarżeń o naruszanie dobrego imienia monarchy. Tego jednak Michajłowski nie uniknął w 1904 r., kiedy został skazany na siedem miesięcy więzienia za pamflet Tajniki pałacu bułgarskiego (Потайностите на българския двореи) $)^{49}$.

\section{Opowiadania i felietony Georgiego Kirkowa}

O ile Michajłowskiego czy Konstantinowa nie można uznać za antyrojalistów (przeprowadzona przez nich krytyka ma uderzać w księcia Ferdynanda oraz pokazać błędy, jakie popełnia, a nie w samą formę rządów), o tyle Georgi Kirkow, będący zagorzałym socjalistą i jednym z przywódców bułgarskiego ruchu robotniczego, otwarcie opowiadał się za likwidacją monarchii oraz ustanowieniem republiki ${ }^{50}$. Kirkow traktował pisanie jako „misję budzenia klasy robotniczej z drobnokapitalistycznego transu i wskazanie jej właściwej drogi klasowej" ${ }^{51}$, posługiwał się zabiegami charakterystycznymi dla ówczesnej estetyki marksistowskiej (pod tym względem najwięcej czerpał od „patriarchy bułgarskiego socjalizmu” Dimitra Błagoewa czy rosyjskiego satyryka Michaiła Sałtykowa-Szczedrina). W ten sposób w twórczości "Majstra” (pod tym pseudonimem najczęściej publikował) doszło do zespolenia satyry polityczno-społecznej z pierwiastkiem propagandowym, które realizował na łamach opowiadań, felietonów, przypowiastek alegorycznych i pamfletów politycznych. Jego utwory miały stanowić polemikę z „dekadenckimi twórcami burżuazyjnymi", za pomocą której starał się udowadniać słuszność marksistowskich praw rozwoju dziejów, zapowiadających rychły upadek kapitalizmu i nadciągający sukces socjalizmu. W przedstawianej przez niego plejadzie zdemonizowanych kapitalistów,

47 Д. Михайлов, op. cit., s. 95; W. Gałązka, op. cit., s. 49-51.

48 W. Gałązka, op. cit., s. 49.

49 Т. Dąbek-Wirgowa, op. cit., s. 149; П. Зарев, op. cit., s. 413; Д. Михайлов, op. cit., s. 102-103.

50 Н. Поппетров, Личността на Георги Кирков като възможност/повод за многостранна историческа реконструкиия, [w:] Георги Кирков и нашето съвремие, red. М. Мизов, Sofia 2007, s. 44.

51 Г. Цанев, Страници от история на българската литература, t. 2: На прелом между две столетия, Sofia 1971, s. 403. 
złodziei, lizusów, lichwiarzy, kameleonów politycznych i demagogów, nie zabrakło także miejsca dla księcia Ferdynanda Koburga, który nie jest wspominany w sposób bezpośredni, a występuje pod rozmaitymi postaciami: chana Kruma, alegorii zwierzęcych, jak i zwyczajnych ludzi: rzeźnika, sprzedawcy lalek, tresera psów ${ }^{52}$.

W utworze satyrycznym Nowina (Новината) Ferdynand zostaje zestawiony z Krumem - chanem, który panował w Bułgarii na początku IX wieku ${ }^{53}$. Średniowieczny władca zasłynął z jednej strony jako wielki zdobywca, a z drugiej - bezwzględny tyran, który przez swoje okrucieństwo zasłużył sobie na przydomek „Straszny” 54 . Symbolem despotycznych metod rządzenia Kruma stały się winnice, które nakazywał niszczyć, by ograniczyć spożycie wina wśród swoich poddanych ${ }^{55}$, do czego nawiązuje Kirkow w opowiadaniu. Zestawiając księcia ze średniowiecznym chanem autor formułuje zarzut wobec Ferdynanda o ustanowienie tyranii w państwie oraz stosowanie barbarzyńskich metod rządzenia. Jednocześnie uznaje, że monarchia jako ustrój jest archaiczna, przestarzała, odpowiadająca bardziej realiom średniowiecza, a nie czasom współczesnym autorowi. W porównaniu Ferdynanda z Krumem, podczas panowania którego państwo bułgarskie obejmowało niemalże powierzchnię całego Półwyspu Bałkańskiego, można także doszukiwać się krytyki zbytniej koncentracji księcia $\mathrm{z}$ dynastii Koburgów na polityce zewnętrznej, nierealnych projektach mocarstwowych i własnym prestiżu. Władca zostaje więc oskarżony o realizację wyłącznie swoich nadmiernych ambicji, swojego - jak to określił Jarosław Rubacha - „snu o Bizancjum” ${ }^{2}$, przy równoczesnym zaniedbywaniu kwestii wewnętrznych kraju jako „nudnych i drugorzędnych" ${ }^{27}$.

W innych utworach satyrycznych Kirkowa krytyka monarchy odbywa się za pomocą alegorii zwierzęcych. W opowiadaniu Kurnik (Кокошарник) Ferdynand występuje pod postacią pawia, który zostaje zaproszony w gościnę do tytułowego kurnika. Zachwycone z odwiedzin znamienitego „obcokrajowca” kury częstują go ziarnem. Nadużywa on ich uprzejmości i pożera całe pożywienie, co doprowadza do powszechnego oburzenia. Mieszkanki kurnika wzywają na pomoc dwa koguty - reprezentujące liberalne poglądy - które po ostrej wymianie zdań zamierzają rozprawić się z łakomym pawiem. Jednak po chwili pojawia się gospodyni. Rozsypuje ona w kurniku ziarno, a zebrani zapominają o nieporozumieniach i przystępują do konsumpcji ${ }^{58}$. Przedstawienie Ferdynanda jako pawia - symbolu wyniosłości,

52 Ibidem, s. 396-419; А. Смочевски, Текст и контекст: национално и универсално в политическите послания на Георги Кирков (140 години по-късно), [w:] Георги Кирков и нашето..., s. 70-80.

53 Г. Кирков, Новината, [w:] idem, Политическа зоология. Разкази и фейлетони, red. И. Гранитски, Sofia 2005, s. 18-19.

54 А. Николов, Хан Крум във византийската традиция: страшни слухове, дезинформация и политическа пропаганда, „Анамнеза”, 2009, t. 9, nr 1, s. 45-59.

55 T. Wasilewski, op. cit., s. 48.

56 J. Rubacha, Bułgarski sen o Bizancjum. Polityka zagraniczna Bułgarii w latach 1878-1913, Warszawa 2004.

57 R. Crampton, op. cit., s. 149.

58 Г. Кирков, Кокочарник, [w:] idem, Политическа зоология. Разкази..., s. 28-32. 
dekadentyzmu, pychy ${ }^{59}$ - ma nie tylko podkreślić obcość wynikającą z jego cudzoziemskiego pochodzenia (naród przedstawiony jest w satyrze pod postacią ptaków innego gatunku - kur), ale także stanowić aluzję do ekstrawagancji oraz plotek o biseksualnych skłonnościach monarchy ${ }^{60}$. Z drugiej strony wymowa satyry zasadza się na podstawowych zarzutach marksizmu wobec społeczeństwa burżuazyjnego - łakomstwo pawia jest metaforą wyzysku stosowanego przez władcę wobec społeczeństwa oraz pomnażania prywatnego majątku przy wykorzystaniu instrumentów władzy. Najbardziej naocznym symbolem owej „,akumulacji kapitału” było wznoszenie nowych willi oraz pałaców, a także przejmowanie na własność ziemi oraz lasów, o czym wspomniałem wcześniej.

Kirkow dokonuje zoomorfizacji Ferdynanda Koburga także w opowiadaniu Wilk-wódz (Вълк-водач). W utworze ukazane jest zgromadzenie owiec, które postanawiają wybrać spośród siebie przywódcę. Po długich debatach oraz odrzuceniu kandydatury barana, osła-filozofa, psa-socjalisty, ostatecznie decydują się powołać na tę funkcję wilka (motywują to faktem, że jest to najsilniejsze zwierzę w lesie). Naiwnie tłumaczą, że w ten sposób nie tylko uchronią się od niebezpieczeństwa $\mathrm{z}$ jego strony, ale i zyskają w nim opiekuna:

Co mówi historia o wilku? Mówi, że jest to krwiożercze zwierzę, które żywi się rabując. Zauważcie, rabując! A czym jest rabunek? Rabunek jest przywłaszczaniem sobie cudzego. Można powiedzieć, że wilk żywi się rabując cudze. Jak wygląda nasz plan? Chcemy uczynić z niego naszego przywódcę, tj. chcemy stać się jego własnością i mieć go na własność. (...) Myślicie, że wilk, wybrany na przywódcę, będzie grabił samego siebie? Nigdy ${ }^{61}$.

Drapieżnik przyjmuje ofertę owiec i w ciągu krótkich rządów pożera większość swoich poddanych ${ }^{62}$. Nie przez przypadek Kirkow posługuje się w opowiadaniu alegorią wilka, symbolizującą zagrożenie, drapieżność, dzikość oraz siłę, a w kulturze chrześcijańskiej (z której autor, mimo poglądów socjalistycznych, bardzo wiele czerpał $\left.{ }^{63}\right)$ - diabła ${ }^{64}$. „Majster” formułuje zarzut, że naród sprzedał się istocie o takich właśnie cechach, która poprzez wyzysk doprowadzi do jego zguby. Wilka-Ferdynanda nie interesuje władza jako taka. Stanowi ona dla niego jedynie środek do zaspokojenia głodu. Zabieg alegoryzacji posłużył Kirkowowi do oskarżenia o przedmiotowe traktowanie poddanych przez monarchę, którego rządy sta-

59 W. Kopaliński, Słownik mitów i tradycji kultury, Warszawa 2003, s. 935-936.

60 S. Constant, op. cit., s. 96; А. Димов, op. cit., s. 66-67.

61 „Какво говори историята за вълка? Говори, че той е едно кървожадно животно, което се храни с грабеж. Забележете, с грабеж! А що е грабеж? Грабеж е присвояване чуждото. Ще рече, че вълкът се храни с грабеж на чуждото. Как стои обаче нашата работа? Ний искаме да го направим наш водач, т.е. да стане неговата собстеност и той наша. (...) Хич, милимо ли е един вълк, направен водач, да ограбва себе си? Никога". Г. Кирков, Вълк-водач, [w:] idem, Политическа зоология. Разкази..., s. 211.

62 Ibidem, s. 209-213.

63 А. Смочевски, op. cit., s. 78.

64 W. Kopaliński, op. cit., s. 1429-1430. 
nowią sformalizowaną formę rabunku prostych ludzi. Tak więc, w opowiadaniu Wilk-wódz autor daje się poznać jako socjalista, dla którego zjawiska polityczne mają $\mathrm{w}$ gruncie rzeczy podłoże ekonomiczne.

Kirkow nie posługiwał się wyłącznie alegorią zwierzęcą, a „nakładał” Ferdynandowi także rozmaite maski zwykłych ludzi. W opowiadaniu Szczeniaki (Палета) monarcha przeistacza się w tresera psów, którego pupile, nazywane przez niego „ministrami”, wykonują każdą zachciankę właściciela, zabawiają go sztuczkami, łaszą się, ciągle walcząc o względy swojego pana ${ }^{65}$. W ten prześmiewczy sposób „Majster” zobrazował specyfikę atmosfery panującej na dworze oraz relacji między monarchą a rządem, który, podobnie jak u Aleko Konstantinowa, tworzą zaślepieni lojaliści, prześcigający się w formułowaniu pochlebstw pod adresem księcia. Podobny obraz wyłania się także z opowiadania Przed rzeźnią (Пред касапницата), w którym Ferdynand jest przedstawiony jako rzeźnik rzucający ochłapy bezpańskim psom w zależności od pochlebstw formułowanych przez głodne czworonogi ${ }^{66}$, a także z utworu Sklep pana Fyrdju Niewiernego (Магазията на господина Фьрдю Манабски), gdzie monarcha pod postacią sprzedawcy lalek dowolnie manipuluje swoimi kukiełkami-ministrami, pociągając za odpowiednie sznurki ${ }^{67}$. Poza krytyką dyktatorskich zapędów księcia, te trzy opowiadania pełnią jeszcze jedną funkcję - przestawienie Ferdynanda Koburga jako szarego człowieka, wykonującego prosty, przyziemny zawód ma dodatkowo zdesakralizować jego osobę, pokazać, że monarcha nie jest boskim pomazańcem, panującym „, Bożej łaski”, lecz zwykłym śmiertelnikiem.

Krytyczny stosunek do monarchy zaprezentowany w utworach „Majstra” oraz Aleko Konstantinowa czy Stojana Michajłowskiego w dużej mierze dotyczy podobnych aspektów kształtowania się „osobistego reżimu” Ferdynanda Koburga. Poza tym obraz księcia został w tekstach satyrycznych Kirkowa rozszerzony o szereg pojęć, zaczerpniętych z ówczesnej krytyki marksistowskiej. Pisarz kładzie szczególny nacisk na czynnik ekonomiczny sprawowania władzy, będącej w rękach księcia zinstytucjonalizowaną formą ograbiania prostych ludzi. Monarchizm, który ze względu na urodzenie oraz przynależność do dynastii, stawia władcę na szczycie hierarchii społecznej, stanowi dla Kirkowa zaprzeczenie nadrzędnej dla niego wartości, jaką jest bezwzględna równość. Stąd przedstawianie w zaprezentowanych opowiadaniach księcia Ferdynanda jako zwykłego człowieka. W ten sposób autor sugeruje, że faktyczne miejsce każdego cesarza, króla, księcia jest wśród zwykłych obywateli. Jednocześnie w tekstach Kirkowa tron stanowi ważny element „reakcyjnego” systemu sprawowania rządów w państwie „burżuazyjnym”, a obalenie monarchii i ustanowienie republiki jest traktowane jako konieczny warunek do wkroczenia w nową rzeczywistość społeczną ${ }^{68}$.

65 Г. Кирков, Палета, [w:] idem, Политическа зоология. Разкази..., s. 125-131.

66 Idem, Пред касапницата, [w:] idem, Политическа зоология. Разкази..., s. 204-208.

67 Idem, Магазията на господина Фгрдю Манафски, [w:] idem, Политическа зоология. Разкази..., s. 226-231.

68 Н. Поппетров, ор. cit., s. 41-44; Н. Ананиева, Георги Кирков във времето и напред в него, [w:] Георги Кирков и намето..., s. 14. 
Analizując biografię oraz specyfikę polityki prowadzonej przez Ferdynanda Koburga nie można uznać, że władza stanowiła dla niego jedynie sposób na „akumulację kapitału”. Jak wspomniano wcześniej, przedstawiciele dynastii Koburgów zrobili w dziewiętnastowiecznej Europie oszałamiającą karierę, a Ferdynand, obejmując tron Bułgarii, nie myślał o zdobyciu pozycji najbogatszego człowieka w kraju. Pieniędzy potrzebował raczej do realizacji swoich ambicji politycznych - dysponowanie własnym, niezależnym od skarbu państwa budżetem pozwalało mu wprowadzać w życie część projektów bez uzyskiwania zgody rządu i parlamentu. Stanowiło to jeden z elementów utrwalających reżim monarszy, szczególnie wobec pogłębiającego się zadłużenia i ciągłego deficytu budżetowego ${ }^{69}$. Należy więc uznać, że wizerunek Ferdynanda jako chana Kruma z utworu Nowina, tresera psów ze Szczeniaków, rzeźnika z Przed rzeźniq oraz lalkarza ze Sklep pana Fyrdju Niewiernego wydaje się bardziej konstruktywną krytyką monarchy niż jego alegoryczne przedstawienie jako pawia oraz wilka, w których uwydatnione zostają ekonomiczne aspekty reżimu. Dla Koburga władza nie była drogą do pieniądza, lecz odwrotnie - majątek miał mu pomóc urzeczywistnić jego „sen o Bizancjum”.

\section{Karykatury z czasopisma „Byłgaran”}

„Byłgaran” jest uznawany za jeden z najważniejszych bułgarskich czasopism humorystycznych, na którym wzorowały się późniejsze periodyki tego typu ${ }^{70}$. Jego redaktor naczelny Aleksandyr Bożinow stworzył wokół niego środowisko bohemy artystycznej, nazywanej „żuczkami” (брбмбазбци) bądź „byłgaranowcami” (българановци), które zbierało się regularnie w karczmie „Środkowy Las” („Средна гора”) na ulicy Rakowskiego w Sofii. Należeli do niej m.in. pisarz Elin Pelin, akademik Aleksandyr Bałabanow, redaktor gazety „Poczta Wieczorna” („Вечерна поща”) Iwan Sławow czy działacz macedoński Christo Siljanow ${ }^{71}$. Karykatury publikowane na łamach tego czasopisma stanowią indywidualne wypowiedzi ich autorów na temat konkretnych wydarzeń, zjawisk oraz graczy bułgarskiej sceny politycznej początku XX wieku. „Żuczki” nie oszczędzały także księcia Ferdynanda, czyniąc z niego bohatera licznych karykatur - monarcha był na nich przedstawiany zarówno bezpośrednio, jak i pod różnymi, zmetaforyzowanymi postaciami: chińskiego mandaryna, potwora, rycerza czy dziecka.

„Byłgaranowcy” często prezentowali monarchę jako dyktatora, który zaprowadził w Bułgarii jednowładztwo, manipulując naiwnymi politykami i społeczeństwem. Za przykład może posłużyć obrazek satyryczny zatytułowany Oto nasi deputowani...

69 R. Crampton, op. cit., s. 162-163.

70 К. Павлова, op. cit.

71 П. Зарев, ор. сit., s. 134-135; Речник на българска литература, t. 1, red. Г. Цанев, Sofia 1976, s. 115-116; Български периодичен печат..., t. 1, s. 115-116; М. Георгиева, Личности в българската карикатура - Александър Божинов като редактор на вестник Българан (1904-1909), „Проблеми на изкуството“", 2012, nr 4, s. 50-59; D. Parusheva, op. cit., s. 51; Елин Пелин, Българановците, [w:] idem, Събрани съчинения, t. 6: Статии, очерии, интервюта и беседи, red. К. Гогов, Sofia 1978, Chitanka.info, http://chitanka.info/text/17325-bylgaranovtsite [dostęp 30.04.2015]. 
(Тук са наш'me депутати...) [Il. 1], na którym grupa członków parlamentu tańczy niczym kukły w rytm melodii wydobywającej się z fujarki centralnej postaci rysunku - księcia ${ }^{72}$. Podobny wydźwięk ma karykatura Wielkanocna zabawka (Великденска играчка) [Il. 2], przedstawiająca Ferdynanda jako chińskiego mandaryna, który bawi się kołatką-lalką, uosabiającą Michaiła Takewa (pełnił on funkcję ministra spraw wewnętrznych w rządzie Aleksandra Malinowa w latach 1908-1911, był jedną $\mathrm{z}$ centralnych postaci obozu rządowego $\mathrm{w}$ tym czasie) ${ }^{73}$. W ten sposób „byłgaranowcy” charakteryzowali księcia jako despotę, wykorzystującego naiwność i oportunizm otaczających go polityków. Karykatury te niewątpliwie treściowo są najbliższe obrazowi ,idealnego tyrana" u Michajłowskiego czy wyobrażeniu monarchy w opowiadaniach Kirkowa. Nie bez przyczyny na drugim $z$ wymienionych rysunków monarcha jest przedstawiony jako chiński mandaryn, uosabiający narodową obcość, barbarzyństwo oraz odmienność mentalną. Podobny wydźwięk ma zresztą karykatura zatytułowana Jak widzi księcia bułgarska młodzież (Как княза си представлява българската младеж) [Il. 3], na której książę Ferdynand został przemieniony $\mathrm{w}$ pokracznego potwora przypominającego skrzyżowanie goryla $\mathrm{z}$ dinozaurem ${ }^{74}$. Taką rysunkową formę przyjęło skierowane pod adresem władcy oskarżenie o prymitywizm, zdehumanizowanie oraz głupotę. W dużej mierze przypominają one zarzuty formułowane przez Kirkowa, dla którego instytucja monarchy uosabiała reakcyjność oraz zacofanie.

Podobnie jak Konstantinow, Michajłowski oraz Kirkow, „byłgaranowcy” chętnie przedstawiali księcia Ferdynanda jako wyzyskiwacza narodu, ciągle nakładającego nowe podatki, niebaczącego na kondycję finansową prostego człowieka. Rysunek zatytułowany Marcowy obyczaj (Мартински обичай) [Il. 4] autorstwa Iwana Sławowa przedstawia monarchę, który za pomocą nożyc wycina ostatnie włoski z łysego już prawie osła, uosabiającego biernie znoszący to naród. Obrazek opatrzony jest następującym komentarzem: „Na tym ośle nie pozostało już nic do strzyżenia, dlatego też zaczniemy go golić"75. Karykaturę należy intepretować w pierwszej kolejności jako krytykę polityki podatkowej państwa, za którą Sławow uczynił odpowiedzialnym księcia Ferdynanda. W 1897 r. obciążenia podatkowe w Bułgarii zostały dwukrotnie podwyższone (z 15,31 lewów per capita do 29,52 w porównaniu do poprzedniej dekady). W latach 1903-1907 po raz pierwszy od 1879 r. dochód państwa z podatku pośredniego przekroczył wpływy z podatku bezpośredniego ${ }^{76}$. Nadmierny fiskalizm ówczesnych władz niewątpliwie przyczynił się do wystąpień społecznych, do jakich doszło w Sofii na przełomie lat 1906 i $1907^{77}$.

72 „Българан”, 1904, R. 1, nr 1 (styczeń), s. 3.

73 „Българан”, 1909, R. 5, nr 23 (28 marca), s. 1.

74 „Българан”, 1907, R. 4, nr 119 (14 stycznia), s. 1.

75 „По това магаре не е останало нищо за стрижене, затова ще почнем вече да го бръснем”. „Българан”, 1906, R. 3, nr 89 (12 marca), s. 7.

76 J. Rubacha, Gospodarka Bułgarii na przełomie XIX i XX wieku, „Słupskie Studia Historyczne”, 2011, nr 17, s. 152-153.

77 Zob. Н. Стретенова, Университетэт и физиците. Начало, Sofia 2000, s. 11-92. 
Interesujące są także karykatury przedstawiające księcia Ferdynanda jako rycerza (a właściwie antyrycerza). Obrazek satyryczny Nowyśw. Jerzy (Новият св. Георги) [Il. 5] autorstwa Petyra Morozowa bezpośrednio odwołuje się do najpopularniejszego przedstawienia wizualnego legendy o św. Jerzym i smoku ${ }^{78}$. Dochodzi jednak tu do całkowitego odwrócenia ról oraz sytuacji: Jerzy-Ferdynand zamiast zabijać bestię dosiada ją, wbijając włócznię w szyję leżącego na ziemi konia, przy której znajduje się pergamin $\mathrm{z}$ napisem „konstytucja”. Karykatura, będąca parodią legendy o św. Jerzym, wyraża myśl, że reżim monarszy stanowi „krzywe zwierciadło” porządku prawnego w państwie. Monarcha zamiast stać na straży konstytucji - ciągle łamie sformułowane w niej zasady, zamiast troszczyć się o swoich poddanych (symbolizowanych przez zabijanego konia) - uciska ich i wyzyskuje, zamiast stanowić wzór cnót i moralności - daje się prowadzić złu (reprezentowanemu przez smoka). W ten sposób Ferdynand, mimo że przedstawiony jako rycerz, staje się ucieleśnieniem systemu wartości będącego zaprzeczeniem etosu rycerskiego. Cechuje go chciwość, a nie hojność, tchórzostwo - a nie odwaga, kłamliwość - a nie wierność danemu słowu, przebiegłość - a nie poszanowanie dla czystej walki, słabość do chłopców, która zastąpiła umiłowanie płci pięknej ${ }^{79}$.

Motyw antyrycerza został także wykorzystany na rysunku satyrycznym zatytułowanym Sen narodu bułgarskiego (Съня на българския народ) [Il. 6] autorstwa Petyra Paspalewa. Historyjka obrazkowa przestawia konia, który zostaje zajeżdżony na śmierć przez okutego w zbroję kawalera, uosabiającego księcia Ferdynanda. Rysunek jest opatrzony następującym komentarzem:

Pewnego razu naród bułgarski głęboko zasnął i śnił, że stał się koniem...

I pewien rycerz, silny i potężny, dosiadł go, a koń pomyślał...

„W sytuacji naszego powszechnego kryzysu - trzeba wybrać nowego przywódcę”...

I jak go rycerz ukłuł dziesięć razy ostrogami, ruszyli...

Pędził koń, kłuł rycerz, pędził koń, kłuł rycerz...

dopóki mu dusza nie uleciała i już się nie obudził... ${ }^{80}$

Obok przedstawienia księcia Ferdynanda jako szalonego, pożeranego przez ambicję tyrana, doprowadzającego swój naród do zguby, wspomniana karykatura krytykuje także elekcję monarchę i związane z nią problemy - formalnie został

78 „Българан”, 1905, R. 2, nr 55 (23 kwietnia), s. 1; W. Kopaliński, op. cit., s. 479; J. Sprutta, Walki, tortury, kary... czyli przemoc w ikonie, „Rocznik Ostrowskiego Towarzystwa Naukowego”, 2009, nr 3-4: O przemocy i wolności, s. 1-4, Otnostrow.org.pl, www.otnostrow.org.pl/pliki/rocznik/2009/10_Sprutta_ tortury.pdf [dostęp 16.04.2015].

79 M. Ossowska, Ethos rycerski i jego odmiany, Warszawa 2000, s. 68-94.

80 „Еднаж българския народ заспа дълбоко и сънува, че е станал кон... \И един рицар силен и могъщ го яхнал и му дума... \ «В нашата областима криза - да идем да изберем нов водител на работите» И като го ритнал десетина пъти с махмузите, тръгнали... \Вървял коня, ръгнал рицаря, вървял коня, ръгнал рицаря... \додето му изкочила душата и не се събудил вече...”. „Българан”, 1908, R. 4, nr 125 (27 stycznia), s. 5. 
on wybrany przez Bułgarów, reprezentowanych przez III Wielkie Zgromadzenie Narodowe (1886-1887), a w praktyce była to decyzja narzucona, podjęta przez wąskie grono najbliższych współpracowników Stambołowa i związana z chłodnymi kalkulacjami politycznymi (a nawet z przekupstwem części delegatów) ${ }^{81}$. Wydźwięk rysunku wydaje się jasny i dosyć fatalistyczny - samostanowienie narodu jest iluzją, a Bułgarzy zmuszeni są do pogodzenia się $\mathrm{z}$ faktami dokonanymi (koń podejmuje decyzje o wyborze wodza, gdy ten już mu siedzi na grzbiecie).

Na łamach „Byłgarana” pojawiły się także karykatury, których autorzy dopełniają wizerunku księcia Ferdynanda, charakteryzując go jako władcę nieudolnego, słabego, który nie jest w stanie podołać wszystkim wyzwaniom, związanym z zarządzaniem państwem (a które zresztą sam na siebie nałożył ustanawiając „osobisty reżim”). By to zobrazować rysownicy wykorzystywali maskę dziecięcą. W ten sposób monarcha jest przedstawiony chociażby na karykaturze zatytułowanej Wielkanocne jајо (Великденско яйце) [Il. 7] autorstwa Petyra Morozowa - Ferdynand jako mały chłopiec otrzymuje od ręki wyłaniającej się z niebios tradycyjną pisankę wielkanocną z literami „ХВ” („Христос воскресе!” - „Chrystus Zmartwychwstał!”) ${ }^{82}$. Podekscytowany zaczyna biec z jajkiem, gdy z kieszeni wysypują mu się monety. Nagle przewraca się, a pisanka rozbija się o ziemię. Karykatura o żartobliwej wymowie nawiązuje do zbliżającej się Wielkanocy, jednak uczynienie z jej głównego bohatera księcia Ferdynanda niesie ze sobą także podtekst polityczny. Przedstawienie władcy jako małego chłopca uaktualnia wszystkie konotacje związane z dziecięcą nieodpowiedzialnością, łobuzerią, niezaradnością, kapryśnością oraz niezdarnością. Dzięki nim rządy monarchy w Bułgarii zostają określone nie jako dyktatorskie czy represyjne, ale nieudolne, napiętnowane przez liczne błędy, znajdujące się „w fazie dzieciństwa", prowadzące do upadku kraju (jajko zostaje rozbite, z kieszeni chłopca wysypują się monety).

Książę Ferdynanda przyjmuje postać dziecka także na karykaturze Bliźniaki - Monarchizm i Parlamentaryzm (Близнаците - Монархизма и Парламента) [Il. 8], która ma zupełnie inny wydźwięk ${ }^{83}$. Można ją zinterpretować jako metaforę kształtowania się reżimu monarszego w Bułgarii, którego istotnym elementem było zachwianie równowagi sił między dworem a parlamentem ${ }^{84}$. Personifikacja monarchizmu jako pucołowatego i rozpieszczanego chłopca w zestawieniu $\mathrm{z}$ jego wychudzonym i dyskryminowanym bratem-parlamentem jest zarzutem braku odpowiednich instytucji kontrolujących władcę. Książę jest bezkarny i nie odpowiada za swoje błędy polityczne, którymi obciąża się przede wszystkim Zgromadzenie Narodowe (lub rząd, co najlepiej obrazują stosunki między monarchą a Stambołowem w latach

81 J. Rubacha, Bułgarski sen..., s. 95-101; А. Димов, op. cit., s. 36-38.

82 „Българан”, 1905, R. 2, nr 54 (17 kwietnia), s. 1; „Христос воскресе!” jest tradycyjną formułą pozdrowienia, którą wymieniają się między sobą prawosławnymi w czasie Świąt Wielkanocnych. Skrótem „XB” lub „ЧXB” zdobi się także pisanki. Ch. Vakarelski, Etnografia Bułgarii, tłum. K. Simiczijew, Wrocław 1965, s. 362.

83 „Българан”, 1908, R. 4, nr 124 (20 stycznia), s. 5.

84 Н. Ананиева, ор. cit., s. 6. 
1887-1894 $\left.{ }^{85}\right)$. Najczęstszym sposobem rozwiązywania niepokoi społecznych przez Ferdynanda było dymisjonowanie rządu i skracanie kadencji parlamentu (jak w 1907 r., kiedy to doszło do odsunięcia stambołowistów od władzy) albo po prostu ich ignorowanie (jak po klęsce w drugiej wojnie bałkańskiej). Dopiero w $1918 \mathrm{r}$. władca został zmuszony do wzięcia odpowiedzialności za klęskę Bułgarii w pierwszej wojnie światowej i zapłacił za to najwyższą cenę - utracił tron.

Infantylizacja księcia została także wykorzystana na karykaturze Aleksandra Bożinowa Jak chłoszcze Byłgaranuś (Как сурваква Българанчо) [Il. 9] ${ }^{86}$. Podobnie jak Wielkanocne jajo, rysunek ma charakter okolicznościowy, związany z Nowym Rokiem 1905, co staje się dla autora okazją do podsumowania minionego roku. Wprawdzie monarcha nie jest przedstawiony na nim jako dziecko, ale zostaje umieszczony w sytuacji typowej dla małego chłopca - personifikacja gazety „Byłgaran” chłoszcze rózgą wypiętą pupę księcia Ferdynanda przełożonego przez kolano. Wydźwięk rysunku wydaje się jasny - bilans rządów księcia w 1904 r. jest oceniany w sposób jednoznacznie negatywny, a monarcha powinien odpowiedzieć za wszystkie błędy polityczne. Infantylizacja wizerunku księcia miała służyć podkreśleniu - wbrew dominacji Koburga na scenie politycznej od połowy lat dziewięćdziesiątych XIX wieku - słabości oraz nieudolności jego rządów, a także przypomnieć, że istnieje niebezpieczeństwo utraty przez niego korony.

Wizerunek monarchy wyłaniający się z karykatur publikowanych na łamach „Byłgarana” nie jest jednorodny. Zbliżony jest do tego, który pojawia się w twórczości Konstantinowa, Michajłowskiego oraz Kirkowa. Mamy tu zatem do czynienia z groteskowym przedstawieniem księcia Ferdynanda jako tyrana, wyzyskiwacza narodu, barbarzyńcy oraz bezideowego manipulanta. Jednocześnie portrety te zostają uzupełnione o nowe elementy, z których najciekawszym jest przedstawienie monarchy jako antyrycerza oraz dziecka. Rysownicy chętnie operują skrajnościami - monarcha często zostaje zaprezentowany jako osoba, która skupia całą władzę państwową w swoich rękach, albo jego rola jest umniejszana, ukazuje się go jako bezradnego, nieudacznego, pozbawionego talentu polityka. $Z$ drugiej strony karykatury „Byłgarana” mają pewne wspólne cechy, przede wszystkim związane z wyolbrzymianiem cech fizycznych księcia Ferdynanda: gigantyczny nos, napęczniałe policzki, wzdęty brzuch, małe oczka, patykowate nogi. Za ich pomocą budowany jest komizm tych postaci.

\section{Podsumowanie}

Książę Ferdynand I Koburg, mimo surowego prawa chroniącego wizerunek monarchy, był jedną z centralnych postaci, na których skupiała się bułgarska twórczość satyryczna przełomu XIX i XX wieku. Analiza tej twórczości wskazuje, że przepisy te były martwe, a przynajmniej działały wybiórczo ${ }^{87}$. Popularność Ferdynanda

85 R. Crampton, op. cit., s. 140-142.

86 „Българан”, 1905, R. 1, nr 40 (1 stycznia), s. 1.

87 R. Crampton, op. cit., s. 177. 
Koburga jako bohatera utworów satyrycznych można łatwo wytłumaczyć. Rotacja premierów, ministrów, deputowanych, czołowych polityków na stanowiskach była duża, podczas gdy władca pozostawał niezmienny, stąd na jego osobie koncentrowała się krytyka wymierzona w funkcjonowanie państwa bułgarskiego. Główne zarzuty pod jego adresem dotyczyły autokratyzmu, odgórnego powoływania szefów rządu, marginalizacji pozycji parlamentu, łamania konstytucji, wykorzystywania władzy do pomnażania osobistego majątku czy braku odpowiedzialności politycznej. W omówionych utworach satyrycznych ustrój monarchiczny zostaje całkowicie odarty z sacrum, a władca pozbawiony podstawowego szacunku, jakim zazwyczaj darzy się głowę państwa. Fakt ten potwierdza powolne wypalanie się rojalizmu w Europie w omawianym okresie, co w następujących słowach ujął Jürgen Osterhammel: „Jeśli, jak czasem się zauważa, ścięcie Ludwika XVI zniszczyło podstawy monarchii jako formy ładu politycznego i świadomości europejskiej, to później miała ona zaznać jeszcze długiej i radosnej agonii" ${ }^{88}$.

$\mathrm{Z}$ drugiej strony, trzeba także postawić pytanie, w jakim stopniu antymonarchizm był postawą rozpowszechnioną $\mathrm{w}$ Bułgarii, a w jakim panował wyłącznie wśród inteligencji, rozczarowanej rzeczywistością polityczną po 1878 roku. Należy pamiętać, że książę Ferdynand cieszył się stosunkowo dużą popularnością wśród społeczeństwa, co było związane z korzystnym bilansem jego rządów do wybuchu wojen bałkańskich: był inicjatorem daleko idących reform gospodarczych, modernizacji wsi, dbał o wysoki poziom przygotowania bojowego armii, w polityce zagranicznej dążył do odbudowy „Wielkiej Bułgarii”. W okresie jego panowania Bułgaria stała się znaczącym graczem w regionie i rozwijającym się gospodarczo krajem ${ }^{89}$. Wyraz poparcia społecznego dla Ferdynanda Koburga możemy znaleźć także w analizowanych utworach: u Michajłowskiego naród sprowadzony jest do roli ślepo oddanej monarsze $r a i^{90}$, w felietonach Kirkow nie może pojąć faktu wielbienia księcia przez prostych ludzi ${ }^{91}$, a na karykaturach „byłgaranowców” obywatele, ukazani za pomogą strzyżonego osła [Il. 4] lub zajeżdżanego na śmierć konia [Il. 6], cechują się biernością i pozwalają się wykorzystywać ${ }^{92}$.

Ferdinand I of Bulgaria in the eyes of mockers. Remarks on Bulgarian political satire at the turn of the $19^{\text {th }}$ and $20^{\text {th }}$ century

The author analyses the evolution of the image of Ferdinand I, Knyaz, and later Tsar (since 1908) of Bulgaria (1887-1918) in Bulgarian satire at the turn of the $19^{\text {th }}$ and $20^{\text {th }}$ century: a collection of short stories about Bay Ganyo by Aleko Konstantinov, the poem Book on the Bulgarian People by Stoyan Mihaylovski, short stories and newspaper columns by Georgi Kirkov and caricatures published in the periodical „Bulgaran”. The above satirists focused on the matter of the mon-

88 J. Osterhammel, op. cit., s. 773.

89 R. Crampton, op. cit., s. 139-140.

90 С. Михайловски, op. cit., s. 313.

91 Г. Кирков, С какво хората живеят, [w:] idem, Политическа зоология. Разкази..., s. 55-56.

92 „Българан”, 1908, R. 4, nr 125 (27 stycznia), s. 5; „Българан”, 1906, R. 3, nr 89 (12 marca), s. 7. 
arch's changing role in relation to the Bulgarian political scene during the latter half of the $1890 \mathrm{~s}$ and the beginning of $20^{\text {th }}$ century, the superficiality of Bulgarian monarchism and the economic aspects of Ferdinand's rule. Due to the strict censorship laws of the time, the monarch was usually depicted in veiled form: as a Turkish pasha, an animal (a wolf, a peacock), an „ordinary man” (a butcher, a puppeteer, a dog trainer), a knight or a child. The main distinctive trait of Bulgarian satire at the turn of the $19^{\text {th }}$ and $20^{\text {th }}$ century was not comicality, but rather the attempt to expose the socio-political anomalies of the young Balkan state.

Translated by Jakub Perliński

\section{Фердинанд I Саксен-Кобург-Готский в глазах пересмешников. Замечания о болгарской политической сатире на изломе XIX и XX веков}

Автор анализирует эволюцию образа князя (после 1908 года - царя) Болгарии Фердинанда I Саксен-Кобург-Готского (1887-1918) в болгарской политической сатире на изломе XIX и XX веков: рассказах «Бай Ганю» Алеко Константинова, поэме «Книга о болгарском народе» Стояна Михайловского, рассказах и фельетонах Георгия Киркова, а также карикатурах из журнала «Българан», редактированного Александром Божиновым. Эти сатирики сосредоточились на проблеме эволюции положения Фердинада Кобургского на болгарской политической сцене во второй половине 1890-х гг. и в начале XX века, поверхностности болгарского роялизма, а также экономических аспектах правления монарха. Из-за действовавшей в Болгарии строгой цензуры, князь обычно изображался в сатирическом творчестве в завуалированном виде: как турецкий паша, животное (волк, павлин), «серый человек» (мясник, кукольник, дрессировщик собак), рыцарь или ребенок. Главной особенностью болгарской сатиры на рубеже веков являлся не комизм, а попытка обличить главные политико-социальные патологии этого молодого балканского государства.

Перевод Агнешка Поспишьль

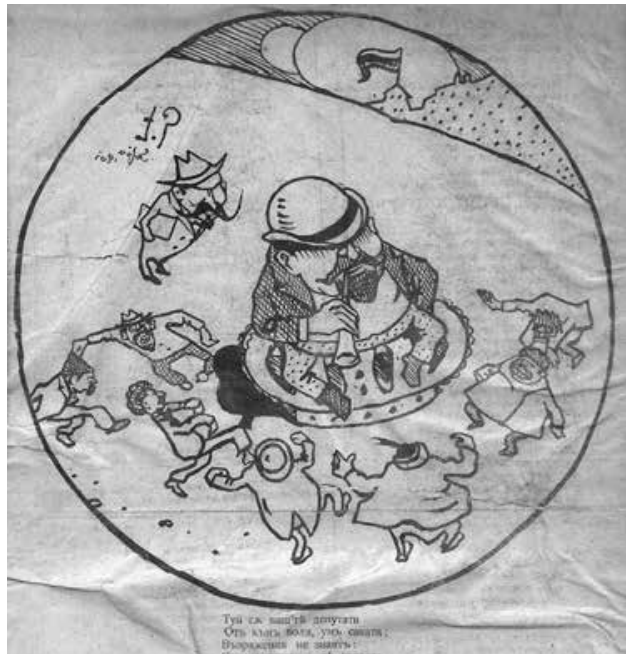

II. 1. Тук са наш'mе депутати..., „Българан", 1904, R. 1, nr 1 (styczeń), s. 1 


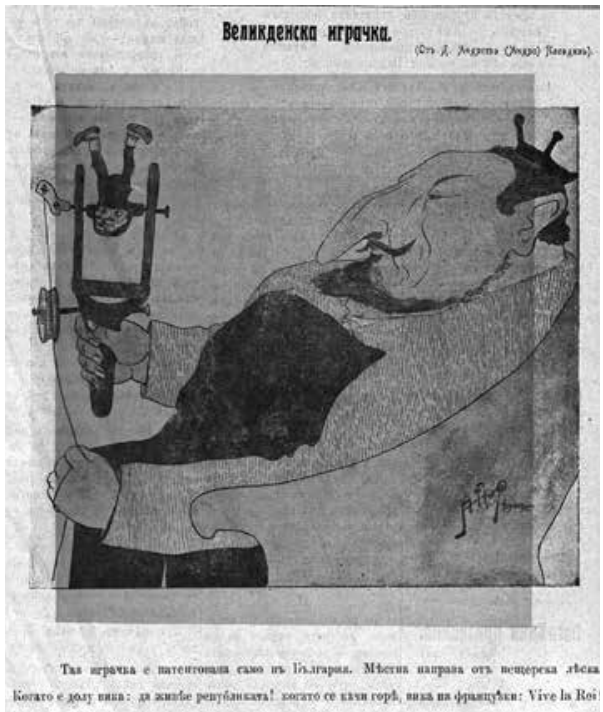

II. 2. Д. Адреев (Андро) Пловдив,

Великденска играчка, „Българан”, 1909, R. 5, nr 23 (28 marca), s. 1

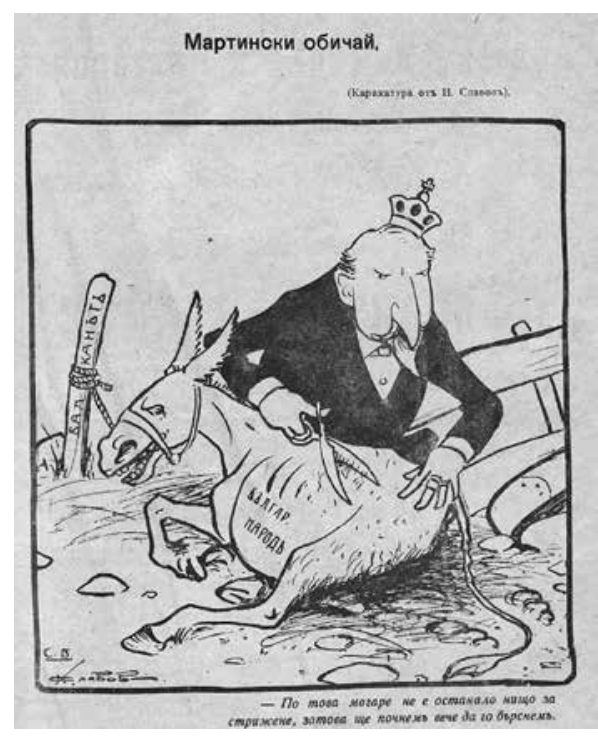

II. 4. И. Славов, Мартински обичай,

„Българан", 1906, R. 3, nr 89 (12 marca), s. 7

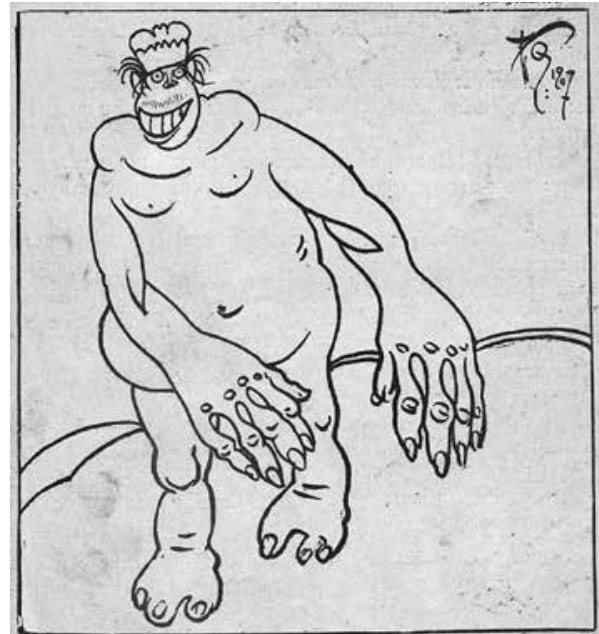

Кізеь княза си прьјетав.лива

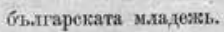

II. 3. А. Божинов, Как княза си представлява българската младеж, „Българан", 1907, R. 4, nr 119 (14 stycznia), s. 1

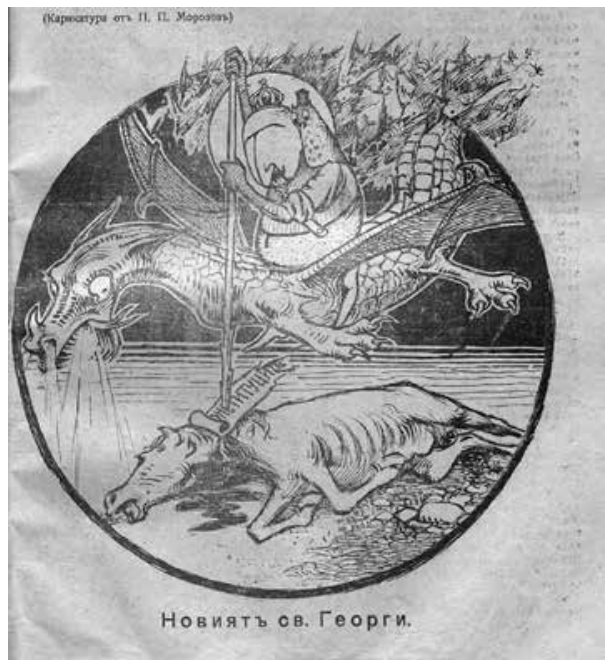

II. 5. П. П. Морозов, Новият св. Георги, „Българан", 1905, R. 2, nr 55 (23 kwietnia), s. 1 


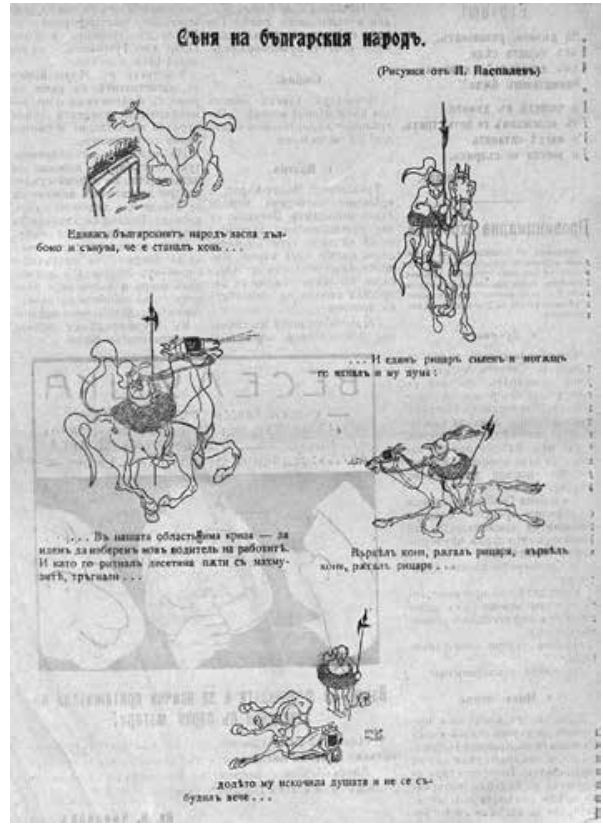

II. 6. П. Паспалев, Съня на българския народ „Българан", 1908, R. 4, nr 125 (27 stycznia), s. 5

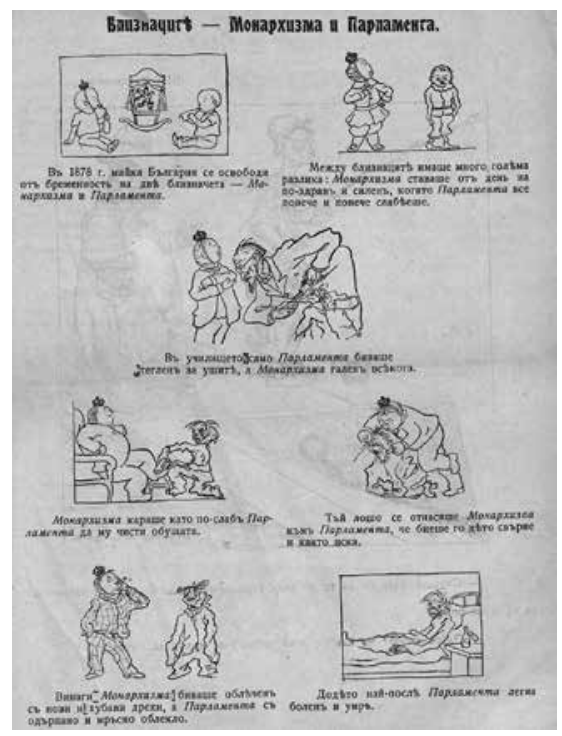

II. 8. Близначите - Монархизма и Парламента, „Българан”, 1908, R. 4, nr 124 (20 stycznia), s. 5

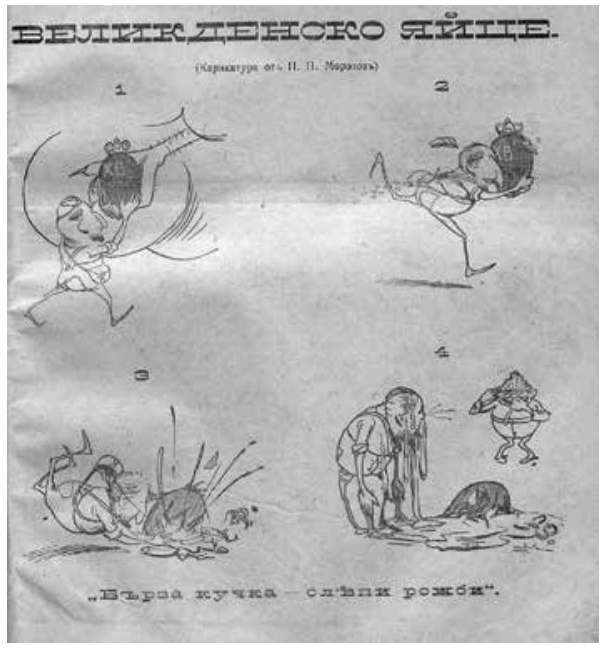

II. 7. П. П. Морозов, Великденско яйце, „Българан", 1905, R. 2, nr 54

(17 kwietnia), s. 1

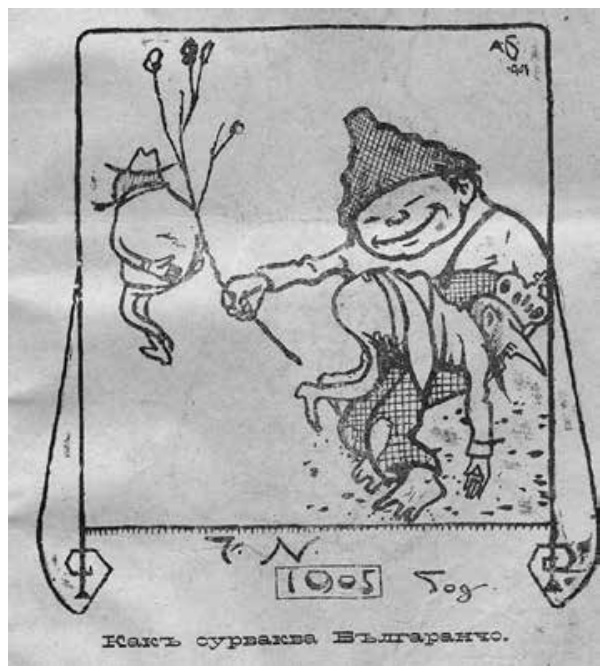

II. 9. А. Божинов, Как сурваква Българанчо, „Българан", 1905, R. 1, nr 40 (1 stycznia), s. 1 


\section{Bibliografia}

Constant S., Foxy Ferdinand, 1861-1948, Tsar of Bulgaria, Londyn 1986.

Crampton R., Bulgaria, Oxford 2008.

Czekalski T., Bułgaria, Warszawa 2010.

Dąbek-Wirgowa T., Historia literatury bułgarskiej, Wrocław 1980.

Felczak W., Wasilewski T., Historia Jugosławii, Wrocław 1985.

Gałązka W., Oswajanie skorpionów. Szkice o literaturze bułgarskiej, Kraków 1992.

Knodt J., Ferdinand der Bulgare, Bielefeld 1947.

Kopaliński W., Słownik mitów i tradycji kultury, Warszawa 2003.

Konstantinow A., Baj Ganiu, tłum. F. Korwin-Szymanowski, Warszawa 1986.

Nowosad A., Władza i media w Bułgarii, Kraków 2008.

Malinowski A., Polityka i pieniądze. Wielkie mocarstwa wobec Bułgarii i jej udziału w I wojnie światowej na przełomie 1914 i 1915 r., [w:] I Wojna Światowa na Bałkanach. Działania militarne i polityczne w latach 1914-1918, red. A. Krzak, Szczecin 2014.

Minczew G., „Watykańscy szpiedzy” i zdrajcy narodu w XIX wieku w Bułgarii, [w:] Obraz zdrajcy i szpiega w kulturach słowiańskich, red. T. Dąbek-Wirgowa, Warszawa 1999.

Ossowska M., Ethos rycerski i jego odmiany, Warszawa 2000.

Osterhammel J., Historia XIX wieku. Przeobrażenie świata, tłum. I. Drozd-Broering, J. Kałążny, A. Peszke, K. Śliwińska, Poznań 2013.

Parusheva D., „They are All Rotters!” Political Culture and Political Caricature in South-Eastern Europe, Late 19th and Early 20th Century, „Études Balkaniques”, 2008, t. 44, nr 4.

Perry D. M., Stefan Stambolov and the Emergence of Modern Bulgaria 1870-1895, Londyn 1993.

Popek K., „Kłótnia $w$ rodzinie”. Upadek protektoratu rosyjskiego w Księstwie Bułgarii w latach 1879-1887, „Studenckie Zeszyty Naukowe UJ”, 2012, nr 4.

Rubacha J., Bułgarski sen o Bizancjum. Polityka zagraniczna Bułgarii w latach 1878-1913, Warszawa 2004.

Rubacha J., Gospodarka Bułgarii na przełomie XIX i XX wieku, „Słupskie Studia Historyczne”, 2011, nr 17.

Rubacha J., Malinowski A. (red.), Historia Bułgarii 1870-1915. Materiały źródłowe z komentarzami, t. 3: Polityka wewnętrzna, Warszawa 2009.

Rusin B., Konstytucja tyrnowska z 1879 r. - historia, ustrój, język, [w:] Historyczna i ponowoczesna tożsamość Słowian, red. T. Ciesielski, J. Zatorska, A. Skoczylas, Łódź 2012.

Sprutta J., Walki, tortury, kary... czyli przemoc w ikonie, „Rocznik Ostrowskiego Towarzystwa Naukowego", 2009, nr 3-4: O przemocy i wolności, Otnostrow.org.pl, www.otnostrow.org.pl/ pliki/rocznik/2009/10_Sprutta_tortury.pdf.

Stępniak T., O satyrze, Katowice 1996.

Wasilewski T., Historia Bułgarii, Wrocław 1988.

Vakarelski Ch., Etnografia Bułgarii, tłum. K. Simiczijew, Wrocław 1965.

Ананиева Н., Георги Кирков във времето и напред в него, [w:] Георги Кирков и нашето съвремие, red. М. Мизов, Sofia 2007.

Ангелов Б., Алеко Константинов, [w:] Страници за Алеко Константинов: Творчеството на писателя в българската литературна критика, red. П. Анчев, Warna 1991.

Бакалов Г., Алеко Константинов и бай Ганьо, [w:] Страници за Алеко Константинов: Творчеството на писателя в българската литературна критика, red. П. Анчев, Warna 1991. „Българан”, Sofia, 1904-1909.

Георгиева М., Личности в българската карикатура - Александър Божинов като редактор на вестник Българан (1904-1909), „Проблеми на изкуството”, 2012, nr 4.

Гочев Д., Георгиев Е., Шалафов И., Истината за иарските имоти в България, Sofia 2011. Даскалов Р., Между Изтока и Запада. Български културни дилеми, София 1998.

Димитрова Ц. Д., Анализ върху критиката за „Бай Ганио” до 1918 г., [w:] Феноменът Бай Ганьо в българската фолклорна и литературна култура от първата половина на ХХ 
век, red. М. Кирова, К. Йорданова, Н. Папучиев, Sofia 2013, Liternet.bg, www.liternet.bg/ ebook/fenomenyt-baj-ganjo/content.htm.

Димов А., Злодеяния на Кобургите в България, Sofia 2013.

Елин Пелин, Събрани съчинения, t. 6: Статии, очерич, интервюта и беседи, red. К. Гогов, Sofia 1978, Chitanka.info, http://chitanka.info/text/17325-bylgaranovtsite.

Зарев П., Панорама на българската литература, t. 2, Sofia 1977.

Иванчев П. (red.), Български периодччен печат 1844-1944, t. 1, Sofia 1966.

Иванчев П. (red.), Български периодичен печат 1844-1944, t. 2, Sofia 1966.

Игов С., История на българската литература 1878-1944, Sofia 1990.

Йовков И., Кобургът, Sofia 1990.

Кирков Г., Политическа зоология. Разкази и фейлетони, red. И. Гранитски, Sofia 2005.

Мешеков И., Бай Ганьо - психологически и обществен тип, [w:] Страници за Алеко Константинов: Творчеството на писателя в българската литературна критика, red. П. Анчев, Warna 1991.

Михайлов Д., Стоян Михайловски: поредиц, творчески портрети, Sofia 1994.

Михайловски С., Избрани творби, red. Б. Банов, Sofia 1976.

Николов А., Хан Крум във византийската традиция: страшни слухове, дезинформаиия и политическа пропаганда, „Анамнеза”, 2009, t. 9, nr 1.

Николова В., Саздов Д. (red.), Програми, програмни документи и устави на бържоазните партии в България 1879-1918, Sofia 1992.

Павлова К., Образбт на бай Ганьо в карикатурите от българския хумористично-сатиричен периодичен печат (1895-1944), [w:] Феноменгт Бай Ганьо в българската фолклорна и литературна култура от първата половина на ХХ век, red. М. Кирова, К. Йорданова, Н. Папучиев, Sofia 2013, Liternet.bg, www.liternet.bg/ebook/fenomenyt-baj-ganjo/content.htm.

Палангурски М., Нова история на България, t. I: Княжество (1879-1911), Sofia 2013.

Поппетров Н., Личността на Георги Кирков като възможност/повод за многостранна историческа реконструкиия, [w:] Георги Кирков и нашето съвремие, red. М. Мизов, Sofia 2007.

Саздов Д., Демократическата партия в България 1887-1908, Sofia 2001.

Саздов Д., Лалков М., Митев Т., Мишев Р., Мигев В. (red.), История на Третата българска държава, Sofia 1992.

Смочевски А., Текст и контекст: национално и универсално в политическите послания на Георги Кирков (140 години по-късно), [w:] Георги Кирков и нашето съвремие, red. М. Мизов, Sofia 2007.

Стателова Е., Иван Евстратиев Гешов или трънливият път на съзиданието, Sofia 1994.

Страшимиров А., Диктаторът. Животът на Стефан Стамболов, Sofia 2014.

Стретенова Н., Университетът и физиците. Начало, Sofia 2000.

Тодоров Г., Временно отменяне и възстановяне на конституиията в Княжество България (1881-1883), Sofia 1991.

Цанев Г., Страници от история на българската литература, t. 2: На прелом между две столетия, Sofia 1971.

Цанев Г. (red.), Речник на българска титература, t. 1, Sofia 1976.

Mgr Krzysztof Popek - doktorant Wydziału Historycznego Uniwersytetu Jagiellońskiego w Krakowie oraz absolwent filologii bułgarskiej tegoż uniwersytetu. Specjalizuje się w dziejach polityczno-społecznych Półwyspu Bałkańskiego w XIX-XX w. ze szczególnym uwzględnieniem historii mniejszości religijnych w Bułgarii, satyry politycznej oraz pamięci o ludobójstwach. Przygotowuje rozprawę doktorską pt. „Polityka państwa bułgarskiego wobec mniejszości muzułmańskiej w latach 1878-1913". (popek.kj@gmail.com) 